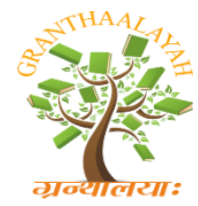

INTERNATIONAL JOURNAL OF RESEARCH GRANTHAALAYAH A knowledge Repository

Management

\title{
USERS PERCEPTION AND USE OF LIBRARY RESOURCE AND SERVICES IN SHRI RAM COLLEGE MUZAFFARNAGAR
}

\author{
Aftab Khan ${ }^{* 1}$, Dr. Javed Khan ${ }^{2}$ \\ ${ }^{* 1}$ Research Scholar, Swami Vivekanand Subharti University, Meerut, India \\ ${ }^{2}$ Associate Professor, Swami Vivekanand Subharti University, Meerut, India
}

DOI: https://doi.org/10.29121/granthaalayah.v4.i12.2016.2410

\begin{abstract}
We speak of today's age as being and information age. An era where information has become the most important aspect of today's social development. The main objective of present study is to find out the users perception and use of Library resources and services in the shri Ram college Muzaffarnagar. Questionnaire is used as a tool of data collection. The questionnaire was developed by researcher. The sample of 178 users has been selected for the study, which include Under Graduate, Post Graduate and Faculty Members of the various departments of Shri Ram College Muzaffarnagar Percentage method was used for the data analysis. The main findings of the study are that the maximum no of users are satisfied with the library resources and services.
\end{abstract}

Keywords: Information; Library Resources; User’s Perception.

Cite This Article: Aftab Khan, and Dr. Javed Khan. (2016). "USERS PERCEPTION AND USE OF LIBRARY RESOURCE AND SERVICES IN SHRI RAM COLLEGE MUZAFFARNAGAR." International Journal of Research - Granthaalayah, 4(12), 208-213. https://doi.org/10.29121/granthaalayah.v4.i12.2016.2410.

\section{Introduction}

Information is recognized as a vital sources and the basic need, for the progress of humanity and the development of a nation, as a whole. It means that every piece of information should be extracted from wherever it is available and provided to the users at the right time, in the right proportion, without delay of time. Only then, can that piece of information be put to its maximum use.

Today, with technology advances and more and more awareness for the need of progress and development, the government is taking a lot of interest in promoting research work and projects. All these activities revolve around information. 
Information is everywhere. We have to categories it organize it and at the same time let the users know about which source contains what information. Only, when the research scholars know about the contents and whereabouts of information can they use it ease, without having someone to assist them. Now-a-days, subjects are multi-displinory in nature because of which, they have become complex. Simultaneously, with the growth in literature there are a number of sources that let us know of the earlier as well as latest developments in a subject. As a result of this growth, the problems of literature explosion have been felt. This tremendous expansion of literature is difficult to be handled or consulted. To make this process easier, attempts have been made to categories to documents, containing information.

\section{Review Literature}

Aina (2014) survey on awareness, accessibility and use of electronic databases among academic staff of Babcock University found that majority of respondents were aware of Academic Journal 59 (69.4percent), followed by JSTOR 48 (56.5percent) as well as Dissertation and Theses with 46 (54.1) and 43(50.6) respectively. The analysis also revealed that majority of respondents were not aware of Bookboon, World Bank Open Knowledge Repository and National Virtual Library with 22(25.9percent), 56 (32.9percent) and 25(29.4) respectively.

Abinew and Vuda (2013) survey on acceptance and use of electronic library services in universities respondents were asked about their awareness of the available e-library services to indicate their answers by way of saying "Yes", "No" and "To some extent". Majority of the respondents (57.97percent) responded "To some extent" to indicate that they have only limited awareness about the existence of e-libraries resources and didn't know well and in detail. 20.65percent of respondents do not know anything about the existence of the e-library services at all. Only 21.38percent of the respondents were well aware of the existence of the e-library services. They also found in the same study that there is no significant difference in awareness of e-library services that existed between universities.

Dange, Girish, Savitha, Sushma and Veenakumari (2013) study on awareness and usage of digital information sources and services by postgraduate students of Kuvempu University revealed that there is significant difference between previous and final year students of digital information sources awareness, digital information services awareness, and digital information sources usage. Also, there is significant difference between arts, science and education postgraduate student's digital information sources awareness, digital information services awareness, digital information sources usage and digital information services usage. But there is no significant difference between previous and final year students' digital information services usage, digital information sources awareness. There is no significant difference between digital information sources usage, digital information services awareness, and digital information services usages of male and female postgraduate students.

Sohail M.D, Pandye A,UpadhyayA.k(2012): conduct the study under the title "Use of library resources in university libraries by students: a survey" studied the use of library resources by the students of University ofKalyani. Authors found the guidance in the use of library resources and services was necessary to help students to meet their information needs. They also found that 
journals, text book and lecture notes were the most popular sources of information for the students.

\section{Objectives of the Study}

1) To find out the users for visiting the library

2) To find out the users awareness about the difference services provided by the library.

3) To find out the users satisfaction with the existing library services.

4) To find out the problem faced by users by using electronic resources in the college library.

\section{Methodology}

The study was conducted using a questionnaire method. The study comprised Under Graduate, Post Graduate and Faculty Members of the various departments of Shrim Ram College Muzzafnager. Altogether there were around 200 Faculty members and Under Graduate, Post Graduate in various departments. Out of this, samples of 178 Under Graduate, Post Graduate and Faculty members were taken at random as they study unit.

The reason for visiting the library

\begin{tabular}{|l|l|l|l|l|l|l|l|}
\hline S. No. & Visiting the Library & \multicolumn{2}{|l|}{$\begin{array}{l}\text { U.G. } \\
\text { N=62 percent }\end{array}$} & \multicolumn{2}{l|}{$\begin{array}{l}\text { P.G. } \\
\text { N=56percent }\end{array}$} & \multicolumn{2}{l|}{$\begin{array}{l}\text { Faculty } \\
\text { N=60percent }\end{array}$} \\
\hline 1. & $\begin{array}{l}\text { To read newspaper and } \\
\text { magazines }\end{array}$ & 36 & 58.06 & 48 & 85.71 & 50 & 83.3 \\
\hline 2. & $\begin{array}{l}\text { To read and borrow books } \\
\text { To find information about } \\
\text { employment }\end{array}$ & 22 & 35.48 & 16 & 28.57 & 10 & 16.6 \\
\hline 3. & $\begin{array}{l}\text { To improve general } \\
\text { knowledge }\end{array}$ & 6 & 9.67 & 16 & 28.57 & 20 & 33.3 \\
\hline 4.
\end{tabular}

(Multiple answer were permitted)

It is observed that about in BIT college 36 (58.06percent) of U.G. students, 48(85.71percent) P.G. students and 50(83.87percent) faculty visiting the library to read newspaper and magazines 52(83.71percent) of U.G. students 40(71.42percent) of P.G. students and 50(83.33percent) of faculty visiting the library to read and borrow books 22(35.48percent) U.G. students 16(28.57percent) P.G. students and 10(16.66percent) of faculty visiting the library to read for examination 6(9.67percent) of U.G students, 16 (28.57percent) and 20(33.33percent) of faculty to find information about employment 16(25.86percent) U.G. students, 32(57.14percent) P.G students and 30(50percent) faculty visiting the library to improve general knowledge.

User's awareness about the difference services provided by the library

\begin{tabular}{|l|l|l|l|l|l|l|l|}
\hline S. No. & Services Provided & \multicolumn{2}{l|}{$\begin{array}{l}\text { U.G. } \\
\text { N=62percent }\end{array}$} & \multicolumn{2}{l|}{$\begin{array}{l}\text { P.G. } \\
\text { N=56percent }\end{array}$} & \multicolumn{2}{l|}{$\begin{array}{l}\text { Faculty } \\
\text { N=60percent }\end{array}$} \\
\hline 1. & Borrowing facility & 42 & 67.74 & 40 & 71.42 & 49 & 81.66 \\
\hline 2. & Reference service & 18 & 29.03 & 40 & 71.42 & 36 & 60 \\
\hline
\end{tabular}




\begin{tabular}{|l|l|l|l|l|l|l|l|}
\hline 3. & Internet facility & 14 & 22.58 & 32 & 57.14 & 50 & 83.33 \\
\hline 4. & OPAC & 14 & 22.58 & 24 & 42.85 & 50 & 83.33 \\
\hline 5. & Bibliographic Service & 2 & 3.22 & 0 & 0 & 20 & 33.33 \\
\hline 6. & Photo copying service & 10 & 16.12 & 24 & 42.85 & 10 & 16.66 \\
\hline
\end{tabular}

(Multiple answer were permitted)

Table show that 42(67.74percent) of U.G. students 40(71.42percent) of P.G. students and 49(81.66percent) of faculty library service satisfaction borrowing facility. 18(29.03percent) of U.G students40(71.42percent) of P.G. students and 36(60percent) faculty reference service. 14(22.58percent) of U.G students32 (57.14percent) P.G. students and 50(83.33percent) of faculty internet facility.14 (22.58percent) of U.G. students, 24(42.85percent) of P.G. students and 50(83.33percent) of faculty OPAC 02 (3.22percent) of U.G. students, No response of P.G. students and 20 (33.33 percent) of faculty bibliographic services. 10(16.12percent) of U.G. students, 24 (42.85percent) of P.G. students and 10 (16.66percent) of faculty photocopying services.

Type of sources of information satisfy by users

\begin{tabular}{|l|l|l|l|l|l|l|l|}
\hline S. No. & Sources of Information & \multicolumn{2}{l|}{$\begin{array}{l}\text { U.G. } \\
\text { N=62percent }\end{array}$} & \multicolumn{2}{l|}{$\begin{array}{l}\text { P.G. } \\
\text { N=56percent }\end{array}$} & \multicolumn{2}{l|}{$\begin{array}{l}\text { Faculty } \\
\text { N=60percent }\end{array}$} \\
\hline 1. & Books and E-Books & 62 & 100 & 40 & 71.42 & 50 & 83.33 \\
\hline 2. & Journal and E-Journal & 18 & 29.03 & 40 & 71.42 & 30 & 50.00 \\
\hline 3. & Print and online Database & 14 & 22.58 & 24 & 42.85 & 30 & 50.00 \\
\hline 4. & CD-ROM/DVD & - & - & - & - & 10 & 16.66 \\
\hline 5. & Indexing and Abstracting & 06 & 9.67 & - & - & 10 & 16.66 \\
\hline 6. & Reference Collection & 14 & 22.58 & 32 & 57.14 & 40 & 66.6 \\
\hline
\end{tabular}

(Multiple answer were permitted)

Table show that 62(100percent) of U.G. students, 40(71.42percent) of P.G. students and 50(83.33percent) faculty book and e-books. 18 (29.03percent) of UG 40(71.42percent) of PG and 30 (50.00percent) of faculty journal and e-journal. 14(22.58percent) of U.G. students, 24(42.85percent) P.G. students and 30(50.00percent) faculty print and online database. No response U.G. and P.G. students, and 10(16.66percent) of faculty CD-ROM/DVD. 06(9.67percent) of U.G. student, no response of P.G. and 10(16.66percent) of faculty indexing and abstracting 14(22.58percent) of U.G. students, 32(57.14percent) P.G. students and 40 (66.66percent) of faculty satisfy with reference collection.

Satisfaction with library service

\begin{tabular}{|l|l|l|l|l|l|l|l|}
\hline S. No. & $\begin{array}{l}\text { Satisfaction with } \\
\text { Library Service }\end{array}$ & \multicolumn{2}{l|}{$\begin{array}{l}\text { U.G } \\
\text { N=62percent }\end{array}$} & \multicolumn{2}{l|}{$\begin{array}{l}\text { P.G } \\
\text { N=56percent }\end{array}$} & \multicolumn{2}{l|}{$\begin{array}{l}\text { Faculty } \\
\text { N=60percent }\end{array}$} \\
\hline 1. & Very Dissatisfied & 04 & 6.66 & 08 & 14.56 & 10 & 16.66 \\
\hline 2. & Dissatisfied & 04 & 6.66 & - & - & - & - \\
\hline 3. & Slightly Dissatisfied & 08 & 12.90 & - & - & - & - \\
\hline 4. & Satisfied & 30 & 48.38 & 16 & 28.57 & 40 & 66.66 \\
\hline 5. & Very Satisfied & 16 & 25.80 & 32 & 57.14 & 10 & 16.66 \\
\hline
\end{tabular}


Table show that 04(6.66percent) U.G. students 08(14.56percent) P.G. students and 10 (16.66percent) of faculty satisfaction with library services very dissatisfied 04(6.66percent) of U.G. students no response P.G. students and no response faculty dissatisfied 08(12.90percent) of U.G. students no response P.G. students and no response faculty slightly dissatisfied 30(48.38percent) U.G. students 16(28.57percent) of P.G. students and 40(66.66percent) faculty satisfied 16(25.80 percent) of U.G. students, 32(57.14percent) P.G. students and 10(16.66percent) faculty very satisfied.

Problem encounter while using electronic resources

\begin{tabular}{|l|l|l|l|l|l|l|l|}
\hline S. No. & Using Electronic & \multicolumn{2}{l|}{$\begin{array}{l}\text { U.G. } \\
\text { Resources }\end{array}$} & \multicolumn{2}{l|}{$\begin{array}{l}\text { P.G } \\
\text { N=56ercent }\end{array}$} & \multicolumn{2}{l|}{$\begin{array}{l}\text { Faculty } \\
\text { N=60percent }\end{array}$} \\
\hline 1. & Information overload & 26 & 41.93 & 16 & 28.57 & 02 & 3.33 \\
\hline 2. & Download delay & 28 & 45.16 & 16 & 28.57 & 04 & 6.66 \\
\hline 3. & Failure to find information & 04 & 6.45 & - & - & - & - \\
\hline 4. & $\begin{array}{l}\text { In accessibility of some } \\
\text { website }\end{array}$ & 12 & 19.35 & 08 & 14.56 & - & - \\
\hline 5. & Break down of the system & 06 & 9.67 & 08 & 14.56 & - & - \\
\hline 6. & $\begin{array}{l}\text { Slow server } \\
\text { Problem of power outage } \\
\text { when using computer }\end{array}$ & 02 & 3.22 & - & - & - & - \\
\hline
\end{tabular}

(Multiple answer were permitted)

Table show that 26(41.93percent) of U.G. students, 16(28.57percent) and 02(3.33percent) of faculty using electronic resources information over load. 28(45.16percent) of U.G. students, 16(28.57percent) of P.G. students and 04(6.66percent) faculty download delay. 04(6.45percent) of U.G. students, no response of P.G. students and no response of faculty failure to find information. 12(19.35percent) of U.G. students, 08(14.56percent) of P.G. students and no response of faculty in accessibility of some website. 06(9.67percent) of U.G. student, 08(14.56percent) of P.G. student and no response of faculty break down of the system. 38(61.29percent) U.G. students, 48(85.71percent) P.G. students and no response faculty slow server 02(3.22percent) of U.G. students, no response P.G. students and no response faculty problem of power outage when using computer.

\section{Findings}

1) The highly percent of U.G students read and borrow books, and the PG, faculty Members are read newspaper and magazines.

2) Mostly users are satisfied by using Books and e-books as a types of sources of information.

3) Maximum of the users the U.G and faculty members are satisfied, and P.G. are also very satisfied with library services.

4) Most of the U.G. \& P.G. students face problem of slow server \& maximum faculty members are facing problems download delay problem encountered while using electronic resources.

5) The high percent of users are satisfied with borrowing facility of library services. 


\section{Suggestions}

- The funds allotted for print material should be spent on more e-resources.

- Library should provide bulletin Board. Service to information the users about the arrivals of journal and latest books.

- The university should introduce the user education program to see the best and maximum use of the library and its collection.

- The timing of the circulation section should be increased the benefit of the users.

- Proper feedback system may be helpful to know about proper use of electronic journals facility.

- The facility and library should organize regular workshops to enhance usage of electronic journals.

- The library should subscribe more number of CD-ROM databases.

- Some mechanisms of awareness about the utility of CD-ROM/online database in the library should be provided.

\section{References}

[1] Abinew, A.A. \&Vuda, S. (2013) "A Case Study of Acceptance and Use of Electronic Library Services in Universities Based on SO-UTAUT Model" International Journal of Innovative Research in Computer and Communication Engineering, 1(4), 903-910.

[2] Aina, R.F. (2014) "Awareness Accessibility and Use of Electronic Databases among Academic Staff of Babcock University”. Business School and Management Review. 3 (6).

[3] Dange, J. K., Girish, T., Savitha, M., Sushma, N. J. \&Veenakumari, (2013) "A study on Awareness and Usage of Digital Information Sources and Services by Post Graduate Students of Kuvempu University" Indian Journal of Education Research Experimentation and Innovation. http://www.ijerei.com/index.php

[4] Khan M.T.M (1998) "Information Organization and Communication" Ess- Ess Publication pg 1633.

[5] Kumar Anil and Singh Jasber (2011) "Awareness and Use of Library Information Resources and Services in Different Universities Libraries in Delhi"Journals of Library \& Information Technology Vol. 7 No. 1 pg 19-38.

[6] Prashar, R.G (1991) "Information and its Communication” New Delhi, Medallian.

[7] Sohail M.D., Pandye A, UpadhyayA.k (2012) "Use of Library Resources in University Libraries by Students: A Survey With Special Reference the University of Kalian" IASIC Bulletin 57(2):122-156.

*Corresponding author.

E-mail address: javedsaim@gmail.com 